\title{
Degradation of orthodontic wires under simulated cariogenic and erosive conditions
}

Laura Cavalcante Lima JABER(a) José Augusto RODRIGUES(b) Flávia Lucisano Botelho AMARAL ${ }^{(a)}$ Fabiana Mantovani Gomes FRANÇA ${ }^{(a)}$

Roberta Tarkany BASTING(a) Cecilia Pedroso TURSSI (a)

(a) Department of Orthodontics, Centro de Pesquisas Odontológicas, Faculdades São Leopoldo Mandic - SLMANDIC, Campinas, SP, Brazil.

(b)Department of Restorative Dentistry, School of Dentistry, Universidade de Guarulhos UNG, Guarulhos, SP, Brazil.
Corresponding Author:

Cecilia Pedroso Turssi

E-mail: cecilia.turssi@gmail.com

DOI: 10.1590/1807-3107BOR-2014.vol28.0024 Epub XXX XX, 2014

Submitted: Sep 26, 2013

Accepted for publication: Feb 25, 2014

Last revision: May 30, 2014

\begin{abstract}
This study examined the effect of cariogenic and erosive challenges (CCs and ECs, respectively) on the degradation of coppernickel-titanium (CuNiTi) orthodontic wires. Sixty wire segments were divided into four treatment groups and exposed to CCs, ECs, artificial saliva, or dry storage (no-treatment control). CC and EC were simulated using a demineralizing solution $(\mathrm{pH} 4.3)$ and a citric acid solution $(\mathrm{pH}$ 2.3), respectively. Following treatment, the average surface roughness (Ra) of the wires was assessed, and friction between the wires and a passive self-ligating bracket was measured. CuNiTi wires subjected to ECs exhibited significantly higher Ra values than did those that were stored in artificial saliva. In contrast, surface roughness was not affected by CCs. Finally, friction between the treated wires and brackets was not affected by ECs or CCs. Our results indicate that CuNiTi orthodontic wires may suffer degradation within the oral cavity, as ECs increased the surface roughness of these wires. However, rougher surfaces did not increase friction between the wire and the passive selfligating bracket.
\end{abstract}

Keywords: Orthodontics; Corrosion; Friction.

\section{Introduction}

Ongoing efforts to improve orthodontic technologies have led to the development of novel wire alloys, including copper-nickel-titanium (CuNiTi) wires. These wires are activated by the temperature within the oral cavity, ${ }^{1}$ which produces beneficial memory effects. They also have greater elasticity, in contrast to conventional stainless steel wires, which must be frequently replaced during initial stages of alignment because of their low elastic recovery. ${ }^{2}$ These attributes of $\mathrm{CuNiTi}$ wires allow for the continuous transmission of force over a long period of time, ${ }^{1,3}$ increasing the time between wire-replacement procedures (10-12 weeks), as compared with stainless steel wires. ${ }^{4}$

The oral cavity is a complex environment, in which orthodontic appliances are subjected to chemical, thermal, and mechanical challenges. ${ }^{5,6,7}$ Appliances typically remain in the oral cavity for prolonged periods of time, making a certain amount of degradation likely. ${ }^{78}$ Acids produced by intraoral bacteria ${ }^{9}$ and from beverages ${ }^{10}$ can cause wire corrosion and affect the physical and mechanical properties of orthodontic wires. ${ }^{6,9}$ Moreover, corrosion increases the roughness of wire surfaces, ${ }^{6}$ 
which leads to wire-bracket friction and reduces the efficiency of orthodontic wires. $5,6,11,12$

Here we exposed thermally activated orthodontic $\mathrm{CuNiTi}$ wires to cariogenic and erosive challenges (CCs and ECs, respectively) in vitro and then assessed wire surface roughness and the amount of friction between brackets and wires.

\section{Methodology}

This study was conducted using a randomized design with "storage condition" as the single experimental factor. Orthodontic wires (Damon Optimal Force Copper NiTi, Ormco, Glendora, USA) were measured with a digimatic caliper (Mitutoyo Sul Americana, São Paulo, Brazil) and cut into 30-mm segments using wire cutters. Sixty wire segments were divided into four groups $(\mathrm{n}=15)$, which were exposed to CCs, ECs, artificial saliva, or dry storage (no-treatment control). The analyzed response variables were surface roughness and friction.

\section{Simulation of CCs and ECs}

A demineralizing solution ( $\mathrm{pH} 4.3)$ was used as the CC. This solution contained $2 \mathrm{mM}$ calcium and 2 $\mathrm{mM}$ phosphate in $74 \mathrm{mM}$ acetate buffer and is commonly used in dynamic physicochemical models of caries. ${ }^{13}$ The ingestion of cariogenic food typically lowers the $\mathrm{pH}$ of saliva and the biofilm microenvironment for $\sim 45 \mathrm{~min}(\mathrm{pH}<5.5)$. As such, $6 \mathrm{~h}$ of immersion in the demineralizing solution corresponds to eight cariogenic challenges, which represent a highly cariogenic condition. To simulate 12 weeks of clinical use, i.e., the typical time that $\mathrm{CuNiTi}$ wires remain in the oral cavity, wire segments were individually immersed in $10 \mathrm{~mL}$ of demineralizing solution for $21 \mathrm{~d}$ ( $24 \mathrm{~h}$ per day), under $37 \pm 1^{\circ} \mathrm{C}$.

A $0.05 \mathrm{M}$ aqueous citric acid solution ( $\mathrm{pH}$ 2.3) was used as the EC. This solution is commonly used as an extrinsic acid in laboratory models of dental erosion. With the assumption that contact between an acidic beverage and a dental structure is normally maintained for $90 \mathrm{sec}$, the experimental wires were individually immersed in $10 \mathrm{~mL}$ of the citric acid solution for $60 \mathrm{~min}$ each day for $21 \mathrm{~d}$, under $37 \pm 1^{\circ} \mathrm{C}$. This simulated 10 erosion episodes per day, which is considered a high EC. ${ }^{14}$ During the remaining daily time (23 h), wires remained dry, under $37 \pm 1{ }^{\circ} \mathrm{C}$.

Wire segments exposed to artificial saliva were individually immersed in $10 \mathrm{~mL}$ of artificial saliva for $21 \mathrm{~d}$ ( $24 \mathrm{~h}$ per day), under $37 \pm 1^{\circ} \mathrm{C}$. The artificial saliva, which mimics the inorganic components and rheological characteristics of natural human saliva, was described by McKnight-Hanes and Whitford ${ }^{15}$ and modified by Amaechi et al. ${ }^{16}$ It was composed of sodium hydroxymethyl benzoate, sodium carboxymethylcellulose, $\mathrm{KCl}, \mathrm{MgCl}_{2} \cdot 6 \mathrm{H}_{2} \mathrm{O}, \mathrm{CaCl}_{2} \cdot 2 \mathrm{H}_{2} \mathrm{O}, \mathrm{K}_{2} \mathrm{HPO}_{4}$, and $\mathrm{KH}_{2} \mathrm{PO}_{4} \cdot{ }^{15,16}$ Wires within the control group were untreated, i.e., they were stored dry, under $37 \pm 1^{\circ} \mathrm{C}$.

\section{Surface roughness assessment}

Each orthodontic wire segment was gently dabbed dry with absorbent paper, and a surface roughness tester (TR200, Time Group, Beijing, China) was used to take five readings of surface roughness. The cutoff value was $0.25 \mathrm{~mm}$ to filter surface waviness. The surface roughness was the arithmetical average value of all absolute distances of the roughness profile from the center line within the measuring length ( $\mathrm{Ra}, \mathrm{mm})$. The surface roughness for each orthodontic wire was the average of the five readings.

\section{Friction testing}

Each wire segment was positioned within a friction testing apparatus, which was mounted on the transverse beam of a universal testing machine (EMIC DL 10000, São José dos Pinhais, Brazil) equipped with a $20-\mathrm{N}$ load cell. The wire segments were positioned parallel to the base of a passive self-ligating bracket (Damon 3 MX, 0.022 × 0.027-inch slot; Ormco, Glendora, USA), which was bonded to the base of the device with a cyanoacrylate adhesive (Loctite Super Bonder Original, Henkel, Itapevi, Brazil).

During testing, mucin-based artificial saliva (50 $\mu \mathrm{L})$ was used to simulate natural human saliva. The artificial saliva contained mucin, xylitol, methylparaben, EDTA, benzalkonium chloride, and $\mathrm{NaF}$ in an aqueous solution, as described. ${ }^{17}$ The force required to move the wire segment $1 \mathrm{~mm}$ at a crosshead speed of $3 \mathrm{~mm} / \mathrm{min}$ was recorded. The test was performed eight times for each wire-bracket set. For each wire segment, a new self-ligating bracket was used. 


\section{Atomic force microscopy (AFM)}

To obtain topographical information about surface roughness, representative wire segments were imaged using AFM(NanoScope V platform, Bruker, Santa Barbara, USA). Measurements were performed in tapping mode.

\section{Statistical analysis}

Data concerning surface roughness and friction were analyzed using the non-parametric KruskalWallis test. Post hoc pairwise comparisons were then made with Dunn's test. Spearman's test was applied to verify correlations between surface roughness and friction. Statistical analyses were performed using SPSS software, version 20 (SPSS, Chicago, USA). Significance level was set at $5 \%$.

\section{Results}

The storage condition significantly affected surface roughness of CuNiTi orthodontic wires $(p=0.004$, Table). Wires exposed to the ECs were significantly rougher than wires stored in artificial saliva. Artificial saliva did not affect roughness, as this group was not different from the untreated group. Wires exposed to CCs exhibited intermediate values of roughness, which were not significantly different from roughness values associated with artificialsaliva or EC groups. Friction between the CuNiTi orthodontic wires and the self-ligating brackets was not affected by the storage condition $(p=0.430)$. Finally, there was no correlation between Ra values and wire-bracket friction $\left(p=0.376 ; \mathrm{r}^{2}=0.116\right)$.

\section{Discussion}

Wires exposed to the EC had significantly higher surface roughness compared with wires exposed to artificial saliva or untreated wires. This result was substantiated by AFM images, which revealed deep valleys in the wire subjected to the ECs (Figure 1d). However, the untreated group also exhibited small surface irregularities (Figure 1a), which likely resulted from the wire manufacturing process. ${ }^{18}$

The immersion of thermally activated NiTi wires in orange juice, soft drinks, or sports drinks does not affect wire topography. ${ }^{10}$ However, immersion times used in this previous study were $~ 95 \%$ shorter than immersion times used in our current study. We
Table. Surface roughness and friction values for CuNiTi wires.

\begin{tabular}{|c|c|c|c|c|}
\hline \multirow{2}{*}{$\begin{array}{l}\text { Storage } \\
\text { condition }\end{array}$} & \multicolumn{2}{|c|}{ Surface roughness (Ra, $\mu \mathrm{m})$} & \multicolumn{2}{|c|}{ Friction (N) } \\
\hline & Mean (s) & Median & Mean (s) & Median \\
\hline $\begin{array}{l}\text { Erosive } \\
\text { solution }\end{array}$ & $\begin{array}{c}0.112 \\
(0.029)\end{array}$ & 0.082 & $\begin{array}{c}1.63 \\
(1.11)\end{array}$ & 1.87 \\
\hline $\begin{array}{l}\text { Cariogenic } \\
\text { solution }\end{array}$ & $\begin{array}{c}0.089 \\
(0.025)\end{array}$ & 0.075 & $\begin{array}{l}1.58 \\
(0.58)\end{array}$ & 1.61 \\
\hline $\begin{array}{l}\text { Artificial } \\
\text { saliva }\end{array}$ & $\begin{array}{c}0.081 \\
(0.012)\end{array}$ & 0.078 & $\begin{array}{c}1.25 \\
(0.68)\end{array}$ & 1.24 \\
\hline Utreated & $\begin{array}{c}0.076 \\
(0.011)\end{array}$ & 0.074 & $1.51(1.3)$ & 1.17 \\
\hline
\end{tabular}

based our immersion times on previous simulations of diet-induced acid erosion ${ }^{19,20}$ and on the amount of time that $\mathrm{CuNiTi}$ wires remain in the oral cavity. It is worth mentioning that the recovery of salivary $\mathrm{pH}$ following the intake of acidic food typically takes $2 \mathrm{~min}$ for anterior teeth and 5-15 min for posterior teeth. ${ }^{21,22}$ Consequently, the effect of ECs on orthodontic wires may be exacerbated. Under clinical conditions, however, the clearing, diluting, and buffering properties of saliva likely help to minimize the deleterious effects of erosive acids.

The CC used in this study simulated situations in which CuNiTi wire comes in contact with bacterial acids. We chose a demineralizing solution that is frequently used in dynamic physicochemical models of caries. ${ }^{23,24,25,26}$ Wires exposed to CCs had intermediate levels of surface roughness, which were not significantly different from roughness measured for the artificial-saliva or EC groups (Figure 1c). This may be because the demineralizing solution had an intermediate $\mathrm{pH}$ of 4.3 in relation citric acid solution and artificial saliva. The lack of a significant difference between the surface roughness of the CC and artificial saliva groups contradicts Bahije et al., ${ }^{9}$ who reported that NiTi wires immersed in artificial saliva with Streptococcus mutans showed more corrosion than controls. This discrepancy may reflect differences between the microbiological model and the physicochemical model that was used in the current study. In addition, Bahije et al. ${ }^{9}$ used an electrochemical approach (rather than surface roughness) to assess the effects of the tested solutions. 

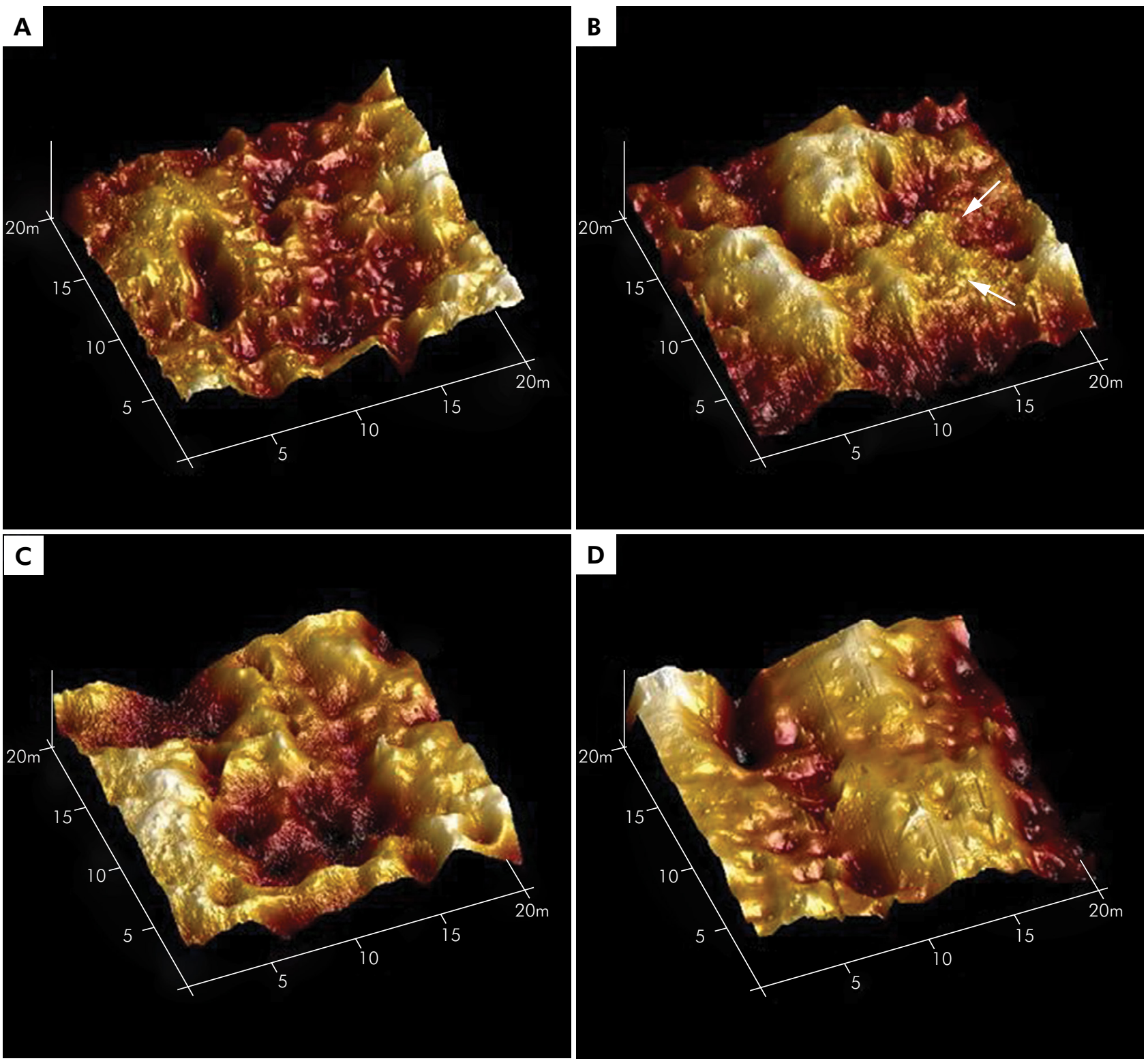

Figure 1. AFM images of orthodontic wires from untreated (a), artificial-saliva (b), CC (c), and EC (d) groups.

CuNiTi wires immersed in artificial saliva had mineral micro-deposits on their surface, as shown by AFM (Figure 1b). Such deposits, which are likely formed by calcium and phosphate, are consistent with previous observations ${ }^{27}$ and result from mineral precipitation, which is expected under laboratory conditions.

Although CuNiTi wire exposed to the EC exhibited corrosive degradation and elevated Ra values, this did not increase the friction between the wire and the self-ligating bracket, i.e., there was not a significant correlation between surface roughness and friction. Therefore, despite wire degradation, sliding of the wire in the bracket slot was not impaired. Thus, the surface roughness of an orthodontic wire cannot predict its friction. ${ }^{5}$ Previous studies, however, have reported associations between surface roughness and friction, ${ }^{6,28,29}$ indicating that additional studies are required to clarify the influence of surface roughness on orthodontic-wire friction.

One factor that may explain the lack of correlation between surface roughness and friction was the use of a mucin-based artificial saliva during the friction test. 
This type of artificial saliva simulates the rheological properties of natural human saliva. ${ }^{17}$ It is possible that if the treated wires had been tested under dry conditions an association between surface roughness and friction would have been revealed. In addition, the friction tests were performed using a passive self-ligating bracket, which produces less friction during sliding and may have influenced the results. Further research is needed to clarify whether other types of brackets, such as active self-ligating brackets, would yield similar results.

\section{References}

1. Gurgel JA, Kerr S, Powers JM, LeCrone V. Force-deflection properties of superelastic nickel-titanium archwires. Am J Orthod Dentofacial Orthop. 2001 Oct;120(4):378-82.

2. Kapila S, Sachdeva R. Mechanical properties and clinical applications of orthodontic wires. Am J Orthod Dentofacial Orthop. 1989 Aug;96(2):100-9.

3. Gil FJ, Planell JA. Effect of copper addition on the superelastic behavioron Ni-Ti shpe memory alloys or orthodontic applications.J Biomed Mater Res. 1999;48(5):682-8.

4. Bennett RK. Extending treatment intervals. Clin Impressions. 2000;9(1):8-13.

5. Bourauel C, Fries T, Drescher D, Plietsch R. Surface roughness of orthodontic wires via atomic force microscopy, laser specular reflectance, and profilometry. Eur J Orthod. 1998 Feb;20(1):79-92.

6. Eliades T, Bourauel C. Intraoral aging of orthodontic materials: the picture we miss and its clinical relevance. Am J Orthod Dentofacial Orthop. 2005 Apr;127(4):403-12.

7. Regis Júnior S, Soares P, Camargo ES, Guariza Filho O, Tanaka O, Maruo H. Biodegradation of orthodontic metallic brackets and associated implications for friction. Am J Orthod Dentofacial Orthop. 2011 Oct;140(4):501-9.

8. Daems J, Celis JP, Willems G. Morphological characterization of as-received and in vivo orthodontic stainless steel archwires. Eur J Orthod. 2009 Jun;31(3):260-5.

9. Bahije L, Benyahia H, El Hamzaoui S, EbnTouhami M, Bengueddour R, Rerhrhaye W et al. Behavior of NiTi in the presence of oral bacteria: corrosion by Streptococcus mutans. Int Orthod. 2011 Mar;9(1):110-9.

10. Parenti SI, Guicciardi S, Melandri C, Sprio S, Lafratta E, Tampieri A, et al. Effect of soft drinks on the physical and chemical features of nickel-titanium-based orthodontic wires. Acta Odontol Scand. 2012 Jan;70(1):49-55.

11. Benyahia H, Ebn Touhami M, Forsal I, Zaoui F, Aalloula E. Corrosion resistance of NiTi in fluoride and acid environments. Int Orthod. 2009 Dec;7(4):322-34.

\section{Conclusions}

CuNiTi orthodontic wires may suffer degradation in the oral cavity, as ECs increased the surface roughness of these wires. However, the rougher surface did not increase friction between the wire and the passive self-ligating bracket.

\section{Acknowledgments}

The authors wish to thank Tatiana Ricci for her technical assistance with the friction testing.

12. Lee TH, Huang TK, Lin SY, Chen LK, Chou MY, Huang HH. Corrosion resistance of different nickel-titanium archwires in acidic fluoride-containing artificial saliva. Angle Orthod. 2010 May;80(3):547-53.

13. Featherstone JDB, O’Really MM, Shariatti M, Brugler S. Enhancement of remineralization in vitro and in vivo. In: Leach AS. Factors relating to demineralization and remineralization of teeth. Oxford: IRL; 1986. p. 23-34.

14. Dugmore CR, Rock WP. A multifactorial analysis of factors associated with dental erosion. Br Dent J. 2004 Mar;196(5):283-6.

15. McKnight-Hanes C, Whitford GM. Fluoride release from three glass ionomer materials and the effects of varnishing with or without finishing. Caries Res. 1992;26(5):345-50.

16. Amaechi BT, Higham SM, Edgar WM. Techniques for the production of dental eroded lesions in vitro. J Oral Rehabil. 1999 Feb;26(2):97-102.

17. Christersson CE, Lindh L, Arnebrant T. Film-forming properties and viscosities of saliva substitutes and human whole saliva. Eur J Oral Sci. 2000 Oct;108(5):418-25.

18. Bentahar Z, Bellamine M, Zertoubi M, Irhzo A, El Boussiri K. Relationship between electrochemical corrosion and the tribologic properties of orthodontic alloys. Int Orthod. 2010 Dec;8(4):360-71.

19. Attin T, Knöfel S, Buchalla W, Tütüncü R. In situ evaluation of different remineralization periods to decrease brushing abrasion of demineralized enamel. Caries res. 2001 MayJun;35(3):216-22.

20. Hara AT, Turssi CP, Teixeira ECN, Serra MC, Cury JA. Abrasive wear on eroded root dentine after different periods of exposure to saliva in situ. Eur J Oral Sci. 2003 Oct;111(5):423-7.

21. Millward A, Shaw L, Harrington E, Smith AJ. Continuous monitoring of salivary flow rate and $\mathrm{pH}$ at the surface of the dentition following consumption of acidic beverages. Caries Res. 1997;31(1):44-9. 
22. Lussi A, Von Salis-Marincek M, Ganss C, Hellwig E, Cheaib $\mathrm{Z}$, Jaeggi T. Clinical study monitoring the $\mathrm{pH}$ on tooth surfaces in patients with and without erosion. Caries Res. 2012;46(6):507-12.

23. Serra MC, Cury JA. The in vitro effect of glass-ionomer cement restoration on enamel subjected to a demineralization and remineralization model. Quintessence Int. 1992 Feb;23(2):143-7.

24. Basting RT, Rodrigues Júnior AL, Serra MC. The effect of $10 \%$ carbamide peroxide bleaching material on microhardness of sound and demineralized enamel and dentin in situ. Oper Dent. 2001 Nov-Dec;26(6):531-9.

25. Turssi CP, Magalhães CS, Serra MC, Rodrigues Júnior AL. Surface roughness assessment of resin-based materials during brushing preceded by $\mathrm{pH}$-cycling simulations. Oper Dent. 2001 Nov-Dec;26(6):576-84.
26. Rodrigues JA, Marchi GM, Serra MC, Hara AT. Visual evaluation of in vitro cariostatic effect of restorative materials associated with dentifrices. Braz Dent J. 2005;16(2):112-8.

27. Huang HH. Surface characterizations and corrosion resistance of nickel-titanium orthodontic archwires in artificial saliva of various degrees of acidity. J Biomed Mater R. 2005 Sep;74(4):629-39.

28. Read-Ward GE Read-Ward GE, Jones SP, Davies EH. A comparison of self-ligating and conventional orthodontic bracket systems. Br J Orthod.1997 Nov;24(4):309-17.

29. Fischer-Brandies H, Es-Souni M, Kock N, Raetzke K, Bock O. Transformation behaviour, chemical composition, surface topography and bending properties of five selected $0.016^{\prime \prime} \mathrm{x}$ 0.022" NiTi archwires. J Orofac Orthop. 2003 Mar;64(2):88-99. 